\title{
DIE LASERFUNKSIE VAN TAAL: OPENBARING OF VERHULLING? 'N TEORETIESE ORIËNTERING
}

\author{
Rensia Robinson \\ Departement Afrikaans Nederlands \\ Universiteit Stellenbosch
}

\begin{abstract}
The conflict of interpretations is a dilemma as well as a challenge to the researcher. The study of poems is not normally considered as directive in such investigations. For the Russian-American philologist Roman Jakobson however, poetry is the working laboratory for the fundamental object language, because it is unique among the varied and often intermarried types and genres of linguistic discourse. Any poetic construction supposes a purposeful choice of language. The aim of this article is to focus attention on insights, which may play a role in readings of such a complicated and problematic text as the Biblical canon. The conclusions of the article are based on a poetical perception of this kind of linguistic activity as the laser function of language and the result of its operation in creating an artistic text.
\end{abstract}

\section{Verantwoording}

Die fokus van my teks- en taalnavorsing is poësie, meer spesifiek Afrikaanse gedigte. 'n Aspek hiervan is die uiteenlopende interaksie van sekere Afrikaanse gedigte met stof uit die Bybelse kanon. My interaksie met Ou- en Nuwe-Testamentiese studies het my oortuig van betekenisvolle raakpunte tussen dié twee kennisvelde. Voor die hand liggend is die feit dat 'n basiese uitgangspunt vir albei studievelde 'n bemoeienis met die funksionering van taal is. Elk het te maak met eiesoortige herskeppings van taal en daarmee gepaardgaande werkbare strategieë vir die hantering van meerduidigheid en veelvlakkigheid. Dit gaan in dié artikel om meer as die eksperimentele toepassing van alternatiewe literêre metodes om ' $n$ bepaalde teks te lees. Dit wil die aandag vestig op sekere talige insigte in die interpretasieproses van artistieke tekste.

Vir Roman Jakobson, Russies-Amerikaanse filoloog, is poësie die aktiewe laboratorium van taal as 'n fundamentele objek (Bradford 1994:126). Sy navorsingsprogram was gerig op 'n linguïstiese ondersoek na die rol en die funksie van grammatikale strukture en die betekenisgenerering van poëtiese tekste. ${ }^{1}$ Dit hou verband met digterlike taal se unieke bemoeienis met die verwikkelde verhouding tussen wat taal is (signans - tekens) en wat dit doen (signatum - be-tekendes). Poësie is nie slegs betekenisvol as eiesoortige taalverskynsel nie. Dit is in 'n hoë mate selfrefleksiewe taal. ${ }^{2}$ Daarom kom Jakobson (in Bradford 1994:2) tot die gevolgtrekking "Poetry is about language, and as a consequence, the poet, as much as the linguist, the semiologist and the philospher, is the pathbreaker in the realms of the sign, the system and the existential condition".

1. Jakobson (1981:769) haal Baudelaire in dié verband soos volg aan: "Grammar, barren grammar, itself becomes something akin to an evocative sorcery... There exists in the word, in the verb, something sacred which prohibits us from viewing it as a mere game of chance. To manipulate language with wisdom is to practice a kind of evocative sorcery".

2. Vgl. Cloete (1970:184) in 'n insiggewende artikel oor die "selfbemoeienis van die "dromende denke" van die digter. 
Jakobson (1981:765) se navorsing het aangetoon dat die poëtiese funksie van taal vanaf die vroegste stadia van taalverwerwing by kinders 'n rol speel asook dat dit 'n sleutelrol vervul in die stukturering van alle diskoers. Alleen op grond hiervan eis dit die aandag op van alle taalwetenskap. David Birch (1989:xiii), soos andere, wys op die geldigheid van Jakobson se navorsing, naas opponerende teoretiese uitgangspunte en gevolglike alternatiewe uitkomste. Hy haal Jakobson soos volg aan: "A linguist deaf to the poetic function of language and a literary scholar indifferent to linguistic problems and unconversant with linguistic methods, are equally flagrant anachronisms". Probleemvelde in verband met kommunikasie, wat Umberto Eco (in Armstrong \& Schooneveld 1977:41) tipeer as 'n eietydse kern vraagstuk, het aanleiding gegee tot Semiotiek as 'n oorkoepelende wetenskap wat verskillende velde integreer. Hy verwys na Jakobson as 'the major 'catalyst' in the contemporary 'semiotic reaction'". Alhoewel laasgenoemde se uitgebreide wetenskaplike oeuvre geen eksplisiete publikasie oor semiotiek bevat nie, wys Eco (in Armstrong \& Schooneveld 1977:42) daarop: “...his entire existence has been a living example of a Quest for Semiotics". Dit is teen hierdie agtergrond dat die artikel die aandag vestig op die funksionering en toepassing van die poëtiese funksie van taal as uitgangspunt vir die ontsluiting van tekste met literêre kwaliteite.

\section{Interdissiplinariteit}

Elke vakkundige ervaar toenemende druk om interdissiplinêr te werk. Dit is egter makliker gesê as gedoen. Dit is nouliks haalbaar om 'n geselekteerde vakgebied te "beheers". Aangrensende of interaktiewe vakgebiede haal dikwels nie meer as die status van voetnotas, oppervlakkige verwysings of selektiewe frases nie. Kermode (1990:83) som hierdie problematiek soos volg op: "There is much more in the interdisciplinary work, which has its dangers. The dangers are, of course, that people get a smattering of something and apply it without really knowing it. It's very difficult to avoid that when all these disciplines have got their own structures and depths... You can't really know it all'. Dit is een van die dilemmas van die onderhawige vakkundige interaksie.

Dit is nietemin met waardering dat ek gebruik maak van die navorsing van Bybelwetenskaplikes omdat die letterkunde eweneens veel te leer het van die Bybelse eksegese en hermeneutiek. Die Bybelse kanon is nie alleen in sigself ' $n$ boeiende en onuitputlike veld vanuit literêr-linguïstiese perspektief nie. Die invloed van die Bybelse kanon as inspirasiebron en interteks in die kuns en letterkunde is so omvattend dat die Engelse digter William Blake tot die gevolgtrekking kon kom: "The Old and New Testaments are the Great Code of Art" (vgl. Northrop Frye, 1982:xvi). In die Afrikaanse letterkunde is dit 'n onomseilbare interteks met uiteenlopende funksies en toepassings. Alter \& Kermode (1987:2) kom desgelyks tot die gevolgtrekking: "The Bible is probably the most important single source of all our literature".

Die feit dat die Ou-Testamentiese boeke en die Christelike kanon aan Universiteite gedoseer word as literêre of artistieke geskrif en in literêre kanons figureer, is sekerlik genoeg bewys dat dit wyer belangstelling geniet as 'n selektiewe geloofsdokument. Dit word literêr gesproke dikwels herken as 'n oorkoepelende narratief, vergelykbaar met antieke tekste soos Die Ilias of die Odussea van Homeros of Vergilius se Aeneid. Sternberg (1987:41) wys byvoorbeeld daarop: "There is the abundant material that, without officially appearing as fiction, yet bears the marks of invention and fulfills the roles of imaginative enhancement and probing of reality associated with it". 'n Groot deel van hierdie verstommende teks het te maak met "unwitnessable events" (Sternberg) - dit dra die tekens van tegnieke van vervreemding (“defamiliarization") wat die verhouding tussen teks en 
konteks problematiseer. Wisseling van taalstrategieë hang saam met verbreding of wysiging van perspektief (vgl. Ricoeur in Mudge 1980:26).

Verskillende universiteite wêreldwyd moes om hierdie rede bykomende kursusse instel om literatuur- en ander kunsstudente vertroud te maak met die inhoud van die Christelike kanon. David Denby (1996:156), skrywer en filmkritikus van die New York Magazine wat 'n kursus geloop het in die klassieke van die Westerse kanon en op dié wyse te doen gehad het met die Ou en Nuwe Testament as letterkunde, kommentarieer soos volg op die OT: "How could a book so defining and inescapable turn out to be so unfamiliar? And so adverse too: Abrupt, imposing and terrible. And not explanatory and comprehensive but baffling and fragmentary. The history of a single people offering itself as authoritative, universal history...". Vanuit 'n literêr-teoretiese perspektief kom Northrop Frye (1982:xvii) tot die gevolgtrekking dat, ten spyte van die lang en verwikkelde redaksionele geskiedenis van die Bybelse kanon, dit die moeite werd is om die eindproduk in eie reg te ondersoek. Wat Eco (1983:82) tipeer as "the tension, the ambiguity and the difficulty which are characteristic of the aesthetic message", is kenmerkend van die Bybelse kanon.

Daar is dus genoegsame rede vir literêr en/of taalkundig geskoolde wetenskaplikes om 'n belangstelling te hê in leesstrategieë waarmee die teks benader (kan) word. Raakpunte tussen die Bybelse wetenskappe en die bestudering van digterlike tekste maak die huidige stand van taalondersoek en die bevindings van taalwetenskaplikes in albei gevalle rigtinggewend. Veral ter sake is die interaksie tussen Poëtika, die wetenskap wat spesifieke kwessies aangaande woordvorming en woordstruktuur ondersoek en Linguïstiek, die oorkoepelende wetenskap vir die ondersoek na woordgedrag. Jakobson (1981:28) wys daarop dat Poëtika dié deel van Linguïstiek is wat die poëtiese funksie in samehang met die ander funksies van taal ondersoek. Afgesien van die eiesoortige taalkundige probleme wat die Bybelse kanon as polivertaalde teks raak, is daar 'n gemeenskaplike tekstuele linguïstiek wat literêr van aard is. Dit kom veral ter sprake waar die Bybelse kanon as artistieke interteks figureer.

\section{Teoretiese oriëntering}

Ten einde rekenskap te gee van die uitgangspunte en gevolgtrekkings waarop die artikel gebaseer is, word toepaslike metodologiese vertrekpunte aangedui. Dit moet egter duidelik gestel word dat dit niks meer wil wees nie as 'n eerste fase van die boeiende maar uitdagende spel van onderskeidend lees. Meir Sternberg (1987) verwys tereg na "the drama of reading", wat in sigself ontwikkeling en wisselwerking veronderstel. Die volgende uitspraak van die Amerikaanse filosoof, William James (in Boorstin 1999:261), is in dié verband 'n belangrike sleutel: "Theories become instruments, not answers to enigmas, in which we can rest... the truth of an idea is not a stagnant property inherent in it".

\section{Die konflik van interpretasies}

Eietydse filosofiese en taal teorieë wat die selfmisleiding en ambivalensie van taaltekens en taaluitinge uitwys, vestig terselfdertyd die aandag op die kreatiwiteit van interpretasie. Tereg kan die stelling gemaak word dat die krisis van representasie postmoderne denke oorheers (Graham Ward 1998:8). 'n Wins van die konflik van interpretasies, soos die titel van een van Ricoeur (1974) se publikasies lui, is dat dit die navorser dwing tot noukeuriger verantwoording. Botsende interpretasies het nie slegs te maak met verskillende maniere van kyk na dieselfde teks nie maar ook met wisselende persepsies van die funksionering van taal. Om hierdie rede is laasgenoemde nie 'n faktor wat buite rekening gelaat kan word nie. 


\section{Teksbenadering - die 'beheerde' oop teks}

Literêre tekste buit die produktiwiteit van taal uit. Te midde van 'n oënskynlike oewerlose spel van moontlikhede wat elke literêre teks bied, kom Umberto Eco (1983:9) egter tot die gevolgtrekking: "In the last analysis what matters is not the various issues in themselves but the mazelike structure of the text. You cannot use the text as you want, but only as the text wants you to use it. An 'open text', however open it be, cannot afford whatever interpretation". 'n Teks impliseer 'n begrensde maar nie 'n ingeperkte ruimte nie. ${ }^{3}$ As komponent van die totale strukturele strategie "omlyn" die "oop teks", volgens Eco (1983:39), sy kompetente leser ("Model Reader"). Daar is nie "oopheid" op enige vlak van 'n teks wat nie ondersteun en bevorder word deur analoë strategieë op alle ander vlakke nie. 'n Kompetente leser is een wat die reëls van die spel ken. Dit veronderstel ook 'n leser wat die kuns om reëls te varieer of om te buig, kan identifiseer. Eco (1983:3) se tipering van die "oop teks" as "a paramount instance of a syntactic-semantico-pragmatic device whose foreseen interpretation is a part of its generative process" (onderstreping van my), is ' $n$ aanduiding van die doelgerigte "speling" wat so 'n teks toelaat. Ricoeur (1995:161) se siening van ' $n$ verbeeldingryke teks as 'n teks wat interpreteer voordat dit geïnterpreteer word, sluit hierby aan. Die "interpretasie dinamiek" van die teks aktiveer 'n "interpretasie dinamiek" in die leser wat, na analogie van dié van die teks, gestuur word. Mens sou kon sê elke lesing/interpretasie van 'n teks werk soos 'n boemerang - dit tipeer die kompetensie van die leser (vgl. Esscher se ets van die hand wat homself "skryf").

As daar een onomwonde saak is, is dit dat die indrukwekkende geskiedenis van eeuelange teksinterpretasie van die Bybelse kanon geen twyfel laat dat dit as 'n "oop teks" met vele uitdagings opereer. Wanneer Ricoeur (in Mudge 1980:104) dit egter tipeer as "one of the great poems of existence", impliseer dit die moontlikheid van 'n gedig as miniatuur analoog. Dit veronderstel 'n maksimaal linguïsties gekodeerde teks.

\section{Implikasies van 'n teks as toegepaste taal}

Noam Chomsky (2000:122), eietydse leidende taalwetenskaplike, vat die huidige bevindings oor taalnavorsing soos volg saam: "A plausible assumption today is that the principles of language are fixed and innate, and that variation is restricted... The conditions of language acquisition make it plain that the process must be largely inner-directed, as in other aspects of growth, which means that all languages must be close to identical, largely fixed by the initial state". Dit impliseer onder andere dat die mens natuurlikerwys oor taalvermoëns beskik waarvan wetenskaplikes nog nie volledig rekenskap kan gee nie. Hierdie bevindings oor taalvermoëns is alles behalwe 'n sleutel tot voor die hand liggende oplossings. Chomsky (2000:128) voeg hieraan toe: "As soon as the first attempts were made to provide actual descriptions of languages 40 years ago, it was discovered that the intricacy of structure is far beyond anything that had been imagined, that traditional descriptions of form and meaning merely skimmed the surface while structuralist ones were almost irrelevant... Proceeding beyond the simplest cases, intricacies mount... As we move on to words with more complex relational properties and the structures in which they appear, we find that interpretation is guided in fine detail by the cognitive system in ways that we expect to vary little because they are so remote from the possible experience."

3. Vgl. (vgl. Lotman in Fokkema \& Kunne-Ibsch 1978:44): "Lotman introduces a semiotic notion of text that includes the linguistic text and the literary text, as well as film, painting or symphony. The text is explicit, i.e. it is expressed in definite signs. It is limited, that is it has a beginning and an end. Finally, it has a structure as a result of an internal organization on the syntagmatic level. As a result of these qualities, the signs of a text enter into a relation of opposition to signs and structures outside the text". 
In digterlike taal word op oënskynlik "on-natuurlike" wyse verbindingsmoontlikhede van taalelemente op intuïtiewe (verbeeldingryke) wyse betekenisvol gestruktureer. ${ }^{4}$ Dit kan moontlik herlei word na bogenoemde aangebore taalkompetensie wat sluimerend is in elke individu. Wat van die analis dikwels moeitevolle rekonstruksie en rekenskap vereis, word deur die verbeelding moeiteloos geskep. ${ }^{5}$ Soos in die fisiese en die biologiese wetenskappe, noop poësie die navorser om die taal te ontgin van die omvattende tot die minuskule. ' $n$ Mens sou kon sê in die digkuns gaan dit om sowel die kosmologie as die argeologie van taal maar ook die fisika daarvan. Die literêre teoretikus, Marianne de Jong (in Senekal 1986:100), verwys na hierdie benadering soos volg: "Elke gedig is terselfdertyd liggaam en molekule; elke geslote gedig as beliggaming van die 'jy' is terselfdertyd molekule in 'n oneindige aanvulbare reeks molekules. Die gedig verskyn (hier) dubbelsinnig: dit is verdig, geslote, ' $n$ geheel van betekenis én dit is gemaak, gevorm uit ander gedigte en slegs na hulle herleibaar ... parasiet en gasheer voed mekaar" (:101). Daar kan met reg verwys word na ' $n$ intrinsieke benadering tot ' $n$ teks as 'n opgrawingsproses wat "diepte semantiek" (Ricoeur 1995:140) na die oppervlakte bring. ${ }^{6}$

'n Fisikus, Colin Cherry (in Halle e.a. 1956: 60), het in 'n bydrae tot 'n bundel opstelle opgedra aan Roman Jakobson daarop gewys: "Philologists and Physicists have this in common, that both study physical phenomena. The utterances of human beings on one hand, and atoms on the other, also share a common feature; there are a fearful lot of both. They cannot all be catalogued, so that abstraction is necessary, the most important factors and properties being singled out and used as the basis of a description". Die hantering en manipulering van hierdie enigmatiese instrument is 'n uitdaging vir wetenskaplike en kunstenaar vir wie alternatiewe funksies van die taal beslissend is.

Jakobson (in Sebeok 1960:352) se uitgangspunt dat elke taalhandeling gebruik maak van en voortbou op die oorkoepelende taalsisteem, word ook weerspieël in die volgende stelling van die Britse linguïs Halliday (1999:536): "It is in the grammar that our experience is construed into meaning". Vir die gebruiker van grammatika moet dit gaan om insig in hoe taal funksioneer (daarom functional grammar). Alhoewel die Linguïstiek nie die sleutel verskaf tot die evaluering van bepaalde literêre eienskappe nie of die interpretasie van die literêre teks nie, voorsien dit leidrade om die teks te beskryf op grond van ' $\mathrm{n}$ algemene taalteorie. Die teks word gelees teen die agtergrond van die oorkoepelende taalstruktuur met bepaalde kommunikatiewe strategieë en inligting (Jefferson \& Robey 1991:70). Vir Halliday (1985:37) is dit voor die handliggend dat indien 'n teks beskryf word, dit na behore gedoen moet word. ${ }^{7}$

Taalwetenskaplikes se siening van 'n teks is dus betekenisvol. Dit word omskryf as "a systemic network of meaning potential" (Halliday 1999:14). Betekenismoontlikhede word oorgedra vanuit die algemene taalsisteem en geïntegreer in 'n nuwe sisteem, nl. 'n teks of weefsel. Dit is 'n doelgerigte proses waarin die potensiaal vir betekenisskepping

4. Vgl. die volgende opmerking van Bradford (1994:18) n.a.v. Jakobson se navorsing oor afasia: “...the poet, at least when writing poetry, is a combination of the aphasic and the psycholinguist or commentator who both understands yet remains aloof from both aphasic conditions".

5. Vgl. Shakespeare in A Midsummer Night's Dream: "The poet's eye, in a fine frenzy rolling, / Doth glance from heaven to earth; / And, as imagination bodies forth / The forms of things unknown, the poet's pen / Turns them to shapes, and gives to airy nothing / A local habitation and a name".

6. Vgl. Ricoeur 1995:24 “.... a succesful hermeneutic plumbs the depths of ...textual strata and brings to light dimensions of sedimented meaning previously hidden and opaque."

7. In sy behandeling van 'n hermeneutiek van lees binne die konteks van literêre teorie verwys Thistleton (1992:499) soos volg na John Barton (Reading the Old Testament 1984): "Following the Saussure-Chomsky usage in linguistics, Barton stresses that 'competence' means 'being in command of the conventions governing the use of a given language-system". 
voortdurend gereguleer word deur wat vooraf gegaan het. Sekere moontlikhede word beperk of uitgesluit terwyl ander as waarskynlik aangebied word of oopgelaat word ter wille van meerduidigheid (Halliday 1999:18). 'n Teks waarin patroonvorming die aandag vestig op die woordstruktuur (weefsel) van die "boodskap", kan getipeer word as 'n artistieke teks (Preminger 1993:698).

Jakobson se teorie is ' $n$ tegniese verantwoording van die totale impak van digterlike taal en nie slegs 'n beskrywing of interpretasie van die leser se bewustelike verstaansproses nie. Dit gaan om die effek van digterlike taal op enige taalgebruiker, of dit nou al bewustelik of onbewustelik geskied (in Jefferson \& Robey 1991:59). Dit verskil van teorieë wat daarop aanspraak maak dat alle taal, ook literêre taal, in die eerste plek sosiaal en ideologies gedetermineer is. Jakobson beklemtoon juis dat woordkuns 'n distansiërende effek het ten opsigte van die ideologieë wat dit inkorporeer. Sodoende stel dit die leser in staat om daarvan bewus te raak as ideologieë. Woordkuns handhaaf 'n eiesoortigheid deur 'n rare linguïstiese bewussyn. Hierdie uitgangspunt word gebaseer op inagneming van relatief verwikkelde taalteorieë (in Jefferson \& Robey 1991:43). Pomorska (in Armstrong \& Schooneveld 1977:369) tipeer woordkuns ("poeticity") op grond van die wyse waarop grammatikale kategorieë betekenisgenerering transformeer as "truly poetic, self-directed "fictions","

Jakobson was in hoofsaak geïnteresseerd daarin om te verstaan hoe 'n bepaalde funksie van taal taalkundig bepaal word (in Birch 1989:119) en watter rol dit speel in 'n kommunikasie handeling. Hy (Jakobson 1981:753) verduidelik die implikasies van hierdie benadering soos volg: "In contrast to one-sided monism and one-sided pluralism, there exists a point of view which combines an awareness of the multiple functions of a poetic work with a comprehension of its integrity, that is to say, that function which unites and determines the poetic work. From this point of view, a poetic work cannot be defined as a work fulfilling neither an exclusively aesthetic function nor an aesthetic function along with other functions; rather, a poetic work is defined as a verbal message whose aesthetic function is its dominent".

Sekere eienskappe van digterlike taal is nie beperk tot kwessies van die taalwetenskap nie. Dit sluit aan by 'n algemene tekenwetenskap of Semiotiek. 'n Semiotiese benadering verreken die transformasie van tekens deur verskillende kodesisteme (vgl. Ricoeur 1995:56). Digterlike taal, soos alle ander woordgedrag, is doelgerig maar die oogmerke verskil. ${ }^{8}$ Die oorkoepelende taalsisteem ("over-all code") sluit sisteme van onderling verbonde subkodes in wat elk 'n vorm van taal impliseer met interaktiewe patroonvorming en wat elk gekarakteriseer word deur 'n verskillende funksie. Dit is vir Jakobson van sleutelbelang dat in elke taalondersoek rekenskap gegee moet word van hierdie onderskeie funksies van taal. Ten einde aandag te gee aan een van hierdie spesifieke funksies, naamlik die poëtiese funksie, is dit belangrik om dit in verhouding te plaas met die ander funksies. Ten einde hierdie funksies te kan onderskei, moet die samestellende elemente in die verbale kommunikasiehandeling in berekening gebring word.

Dit is met die besef dat betekenisvorming in tekste, ondanks die kompleksiteit daarvan, nie ' $n$ willekeurige proses is nie, dat teoretici, met gebruikmaking van tot dusver bestaande insigte, heuristiese modelle skep waarvolgens betekenistoekenning in 'n bepaalde teks of konteks beskryf en gemotiveer kan word. Roman Jakobson se sogenaamde ses funksies model is 'n konsekwente en verfynde toepassing van taalkundige insigte in die teoretisering oor literêre sowel as nie-literêre tekste (vgl. Jefferson \& Robey 1991:43).

8. Vgl. Eco (1983:82) se opmerking: "Language makes a gesture", en TT Cloete se tipering van die digter as 'n figuur wat 'onderstebo' kyk en met 2 linkerhande in die Paser 1-gedig (1998:70). 


\section{Skematisering van narratiewe seleksie en rangskikking ('narrative selection and arrangement')}

Gräbe (in Cloete 1992/11:471) wys daarop hoe, in 'n proses van semantisering, nie net alle latente woordeboekbetekenisse van 'n woord uitgebuit word nie, maar die tekstuele omgewing waarbinne dit voorkom - poëties, narratief of dramaties - die woord laai met ekstra konnotasies wat dit normaalweg nie sou hê nie. Jakobson se tekslinguïstiese benadering se oogmerk is om die geheel van verhoudinge wat in 'n teks tot stand kom, te onderskei. Sy kommunikasiemodel wat die verwikkelde verhouding tussen outeur, teks en leser verduidelik, stel die navorser in staat om noukeuriger rekenskap te gee van die talige tekstuur. Resultate van interpretasie hang in 'n groot mate saam met hoe so 'n kommunikasiemodel opgevat en ontgin word. ${ }^{9}$

Die kategorieë sender, ontvanger en konteks is onontbeerlik in die verstaan van elke kommunikasiehandeling. Die sender en die ontvanger is nie sonder meer twee pole van die kommunikasiehandeling nie maar tree op as aktansiële rolle van die sintaksis. Die aktant is die instansie wat tekstueel gebeurtenisse veroorsaak of handelinge onderneem. Die "outeur" (dus nie die reële outeur nie) is 'n tekstuele strategie wat semantiese verbande skep en die "model leser" stimuleer. Eco (1983:10) haal Kristeva soos volg aan in dié verband: "Usually this conjuring up of the 'ghost' of the sender is ordered to a symmetrical conjuring up of the 'ghost' of the addressee". Die "outeur" is identifiseerbaar as 'n styl of teks idiolek wat nie noodwendig 'n individu verteenwoordiug nie maar alternatiewelik 'n genre, sosiale groep of historiese periode. Die idiolek word gerekonstrueer deur te let op terugkerende inligting in die teks (Ohloff in Cloete 1992/11:222). Wanneer na die "boodskap" verwys word, gaan dit om 'n teks wat 'n netwerk boodskappe dra, gebaseer op kodes wat op verskillende vlakke van betekenisvorming funksioneer (Eco 1983:4,5).

Betekenisskepping en verstaanbaarheid is in 'n belangrike mate van gedeelde kodes afhanklik. Kode verwys na enige primêre tekensisteem wat informasie, gebaseer op reëls/konvensies wat hulle kombinasie binne 'n taalkonstruk reguleer, tussen 'n sender en ontvanger oordra. Menslike taalgebruik is van die hoogs ontwikkelde kodesisteme wat aan ons bekend is (Ohlhoff in Cloete 1992:221). Terwyl kodes enersyds grense reguleer, skep dit andersyds verbande en verhoudinge wat kreatiewe betekenisgenerering stimuleer (vgl. Ricoeur 1995:56). Dit verklaar waarom 'n gedig wat maksimaal gekodeer is (getipeer as "gebonde taal"), terselfdertyd polisemies kan wees. Die aantal kodes wat bydra tot die opbou van die teks, verruim die skopus van die teks en die inligtingnetwerk wat die teks dra. Die ontvanger se resepsie van teksinligting sal saamhang met kennis van die aantal kodes wat in die teks opereer (Fokkema n.a.v. Lotman 1985:647). Die interpretasie van verwikkelde taaluitinge veronderstel die toepaslike gebruik van 'n hele aantal kodes gelyktydig (Scholes 1982:143). Kodes kan nie volledig afgerond word nie. Fokkema (1985:647) tipeer die finale teks tereg as 'n produk van "hiperseleksie" (hyperselection).

Elkeen van dié ses bydraende komponente van die kommunikasiehandeling determineer 'n ander funksie van taal. Alhoewel ses verskillende funksies ooreenkomstig geïdentifiseer word (emotief, referensieel, poëties, faties, metalinguaal en konatief), is daar haas geen talige teks waarin slegs een van hierdie funksies opereer nie. Die diversiteit van tekste hang nie saam met ' $n$ monopolie van een funksie in 'n bepaalde teks nie maar in die hierargiese ordening van verskillende funksies in dieselfde teks. Alle woordgedrag maak gebruik van beginsels van opposisie en hiërargie. In die geval van digterlike taalgebruik moet die funksie van die spesifieke hierargisering van elemente ondersoek word sowel as die interaksie

9. Vgl. Scholes $1979: 144$ - "the variety of readings which we have for many works is a function of the selection of crucial aspects made by the variety of readers". 
tussen elemente en die geheel (Pomorska in Armstrong \& Schooneveld 1977:364). Omdat die dominante funksie van 'n teks die ander samestellende faktore stuur, bepaal en transformeer, spesifiseer dit die tekstipe. "It is the dominant which guarantees the integrity of the structure," sê Jakobson (1981:751).

Elke taalhandeling is konteksgebonde - d.w.s. skep 'n bepaalde verwysingsraamwerk (Jakobson in Sebeok 1960:353). Betekenisskepping in vartistieke teks behels 'n voortdurende interaksie tussen verskillende kontekste wat nie eksplisiet aanwesig is in die teks nie maar wat onontbeerlik is vir die realisering daarvan (Scholes 1979:147). Inagneming van die poëtiese funksie wat fokus op betekenisgenerering van die teksstruktuur (in plaas daarvan om te vra na die intensie van die reële outeur), kan dus die konteks van die outeur deurbreek of oorstyg. Dit mag ook konteksgebondenheid van die leser aan die lig bring (Mudge n.a.v. Ricoeur 1980:25). Teenoor teorieë wat die literêre kunstenaar sien as bepalende instansie wat die sosiale, ideologiese en linguïstiese spektrum van 'n bepaalde milieu rekonstrueer, beklemtoon Jakobson dat die poëtiese teks 'n selfgenoegsame milieu is, tegelykertyd ' $n$ afhanklike en 'n ahistoriese taalsisteem wat die individualiteit van die kunstenaar absorbeer en perspektiewe op die "wêreld" reflekteer (Bradford 1994:176). Die leser verkry deur die artistieke teks toegang tot 'n herbeskrywing van die "werklikheid" waarin hy/sy ook getransformeer word tot deelnemer. Jefferson (in Jefferson \& Robey 1991:110) verduidelik dit soos volg: "If the text represents anything 'real' at all, it is only the difficulty of representation ... representation is replaced by reflexivity... Truth is similarly found to have no real status in the literary text... By posing an enigma and deferring its solution, the hermeneutic code pulls of a sleight hand which makes delayed information synonymous with truth. Truth is not something fixed and solid beyond and behind the literary text, and to which the text can be reduced: It is simply what comes last in the text". Ricoeur (1995:8) beklemtoon ook dat die meerderheid poëtiese tekste wel na "die werklikheid" of die "wêreld" verwys, maar met dié kwalifikasie: “...not the world accessible to thorough going positivism and aestheticism, but the world now refigured under the tutelage of the imaginary and the possible. Poetic language does intend reality - it is not a language unto itself divorced from any referential function - but its power of reference is the power to set forth novel ontologies that disorient readers in order to reorient them by way of an over-expanding vision of the whole". Daarom word die oorspronklike Sitz-im-Leben verplaas deur die Sitz-im-Wort, 'n tekstuele konteks waarin gebeure, handelinge en instellings hulle oorspronklike bestaanswyse (wortels) suspendeer om opgeneem te word in en herdefinieer te word deur nuwe verbande (Vgl. Ricoeur 1995:171).

$\mathrm{Na}$ aanleiding van die beskuldiging dat sy teorie aangaande die poëtiese funksie die verhouding tussen artistieke teks en sosiale konteks ("real life") ignoreer, wys Jakobson daarop dat woordkuns, semioties gesien, ' $n$ integrale deel is van die sosiale struktuur. Dit is één komponent daarvan wat in voortdurende wisselwerking met alle ander komponente in 'n dialektiese verhouding staan. Jakobson (1981:749) se teoretiese uitgangspunte isoleer nie die artistieke skepping in 'n soort ivoortoring nie maar beklemtoon slegs die outonomie van die estetiese funksie wat betekenisgenerering in die teks stuur. 'n Tekstipologie het dus ook 'n pragmatiese komponent wat sosiale en psigologiese konvensies in berekening bring wat nie tot die sintaksis of semantiek gereken word nie (Vgl. Van Dijk 1971:69, 70). Elke taalsisteem maak aanspraak op betroubaarheid. Dit word egter op verskillende maniere hanteer. Digterlike taal gaan anders te werk met die taalsisteem as 'n formele inligtingstuk.

Deel van die interaksie van verskillende kontekste, is die aanwesigheid van of die vervlegtheid met ander tekste. Dit is toenemend begryp in watter mate "elke teks na voorafgaande tekste verwys" (Eco 1983:19). Dit gaan in die verstaansproses egter nie slegs om 'n herkenning van die aanwesigheid van ander tekste nie. Dit gaan om verbandlegging 
en verhoudinge. Waar een teks verwys na 'n ander teks, verplaas of ontken dit nie die oorspronklike nie. Dit ontvang van die interteks 'n uitbreiding van betekenismoontlikhede (Ricoeur 1995:148). Betekenistoekenning veronderstel 'n volhardende wisselwerking tussen die tekswêreld en 'n netwerk kontekste wat nie eksplisiet aanwesig is nie maar noodsaaklik is vir die realisering van die teks (Scholes 1979:147). Soos alle linguïstiese studies, raak dit diachronie en sinchronie. Poëtika en linguïstiek is dus geïnteresseerd in veranderinge sowel as statiese faktore (Sebeok 1960:352).

Volgens Scholes (1979:144) verskil die lees van 'n teks in dié opsig van projeksies oor 'n teks dat eersgenoemde die outonomie en die eiesoortigheid van die teks respekteer terwyl projeksies met nie een van dié twee erns maak nie. Daarom kan Todorov (in Scholes 1979:145) die onderskeiding tref dat dit nie gaan om ware of vals lesings van 'n teks nie maar om lesings wat gevarieerd is óf minder toepaslik.

\section{Die poëtiese funksie van taal}

Wanneer die poëtiese funksie 'n dominante rol vervul in 'n teks, verskuif die klem van die oordrag van inligting (met realiteitsverifiëring as oogmerk) na die "hoe" van representasie. Eco (1983:39) wys daarop: "In poetry the most happens at the level of semantic disclosures and at that of deepest intensional structures". Hierdie soort teks is 'n doelgerigte en geïntegreerde konstruk met sy eie immanente reëls (Bradford 1994:26). Betekenisgenerering word bepaal en beperk deur die formele ordening van die teks (boodskap). Daarom moet dit ontleed en verduidelik word in samehang met die ander bydraende elemente van die poëtikale konstruk sowel as in samehang met die geheel. Daarom kan Stankiewicz (in Sebeok 1960:70) tot die gevolgtrekking kom: "By taking into account the underlying linguistic structure, the study of poetic language becomes thus a study of a certain type of rearrangement and modification of the elements of everyday spoken language".

Hierdie teoretiese uitgangspunte lê ten grondslag van Jakobson (1981:27) se sleuteluitspraak in verband met die tipering of onderskeiding van die poëtiese funksie: "The poetic function projects the principle of equivalence from the axis of selection into the axis of combination. Equivalence is promoted to the constitutive device of the sequence".

Vir Jakobson is paralellisme ('n tegniek van ekwivalensie) die essensiële en basiese beginsel ten grondslag van alle patroonvorming en verbandlegging in woordkuns. ${ }^{10}$ Elke vlak word opgebou uit 'n vorige. Jukstaponering van elemente vestig die aandag op ooreenkomste. Parallelismes word geskep deur semantiese sowel as fonologiese verwantskap ("the phonico-semantic knot" - Pomorska in Armstrong en Schooneveld 1977:374). Die volgende uitspraak van die Engelse digter, Gerard Manley Hopkins, beskou Jakobson as ' $n$ kerninsig in verband met die funksionering van digterlike taal:

"The artificial part of poetry, perhaps we shall be right to say all artifice, reduces itself to the principle of parallelism. The structure of poetry is that of continuous parallelism, ranging from the technical so-called Parallelisms of Hebrew poetry and the antiphons of Church music to the intricacy of Greek or Italian or English verse."

Jakobson (1981:99) wys verder daarop dat die Bybelse Parallelismus Membrorum eerstens die aandag getrek het van Westerse wetenskaplikes. Dit was Robert Lowth se The Preliminary Dissertation by sy vertaling van Jesaja, die eerste keer gepubliseer in 1778 , waarin die fondament gelê is vir 'n sistematiese ondersoek na die woordstruktuur van antieke Hebreeuse poësie. Hieraan is die begrip "parallelisme" ontleen as 'n tipering van

10. “...On every level of language the essence of poetic artifice consists in recurrent returns” (Jakobson 1981:98). 
woordkuns. ${ }^{11}$ Dit is veral betekenisvol dat Jakobson se navorsing aan die lig gebring het dat poëtiese patrone waarin ooreenkomste tussen opeenvolgende reekse (semanties/fonologies) dwingend is of hoë voorkeur geniet, wyd verspreid voorkom in tale dwarsdeur die wêreld. Navorsing van hierdie soort taalgedrag is vir die studie van poëtikale analise sowel as vir grammatikale verskynsels in die algemeen buitengewoon vrugbaar. Hierdie tradisionele tipes van kanonieke parallelisme gee insig in die verskillende soorte verbande en samehang tussen die onderskeie elemente van 'n taalkonstruk. 'n Ondersoek hierna help die analis om vas te stel watter verwante grammatikale en fonologiese kategorieë optree as ekwivalent binne gegewe patroonvormings. Jurij Lotman (aangehaal in Jakobson 1981:768) vergelyk die artistieke funksie van grammatikale patrone in literêre tekste met die spel van geometriese strukture in beeldende kuns.

\section{Die aard van digterlike taal}

'n Relevante vraag is of tekste waarin die poëtiese funksie dominant is so gesofistikeerd is dat dit slegs deur teoretici ontsyfer (en geniet!) kan word? Digterlike taal word dikwels populêrweg ervaar as 'n esoteriese bedryf van diegene wat met verbeelding gepla is. Die 18de eeuse Italiaanse filosoof Giambattista Vico het egter al geredeneer dat aan die begin alle taal poësie (of metafories) moes gewees het. Hy het beweer: "The appeal of the first sound was like the appeal of poetry; it was pleasurable and fit to symbolize" (Roberts 2000:127). Greimas (in Schleifer 1987:152) wys daarop: “...poetic language, while remaining part of language, seeks to reachieve the 'primal cry', and thus is situated midway between simple articulation and a linguistic double articulation. It results in a 'meaningeffect' ... which is that of 'rediscovered truth' which is original and originary according to the particular case". Volgens die Britse kunskritikus en digter, John Ruskin, neem die groot kunswerk jou op vleuels wat 'n visioen vir jou oopmaak wat jou laat vergeet van die wondertapyt (die teks) waarop jy ry. Die prestasie van groot kuns word dikwels ook die moeitelose ontdekking van die mees naïwe leser of toneelganger wat, onbewus van die vorm, die "verhaal" as "werklikheid" beleef (Shipley 1968:30). Hierdie bevindings sluit aan by dié van linguïste wat handel oor aangebore taalkompetensie waarna ek aan die begin verwys het. Mark Turner (1991:168) beweer selfs: "Language is the child of the literary mind". ${ }^{12}$

Hoe herwin 'n ooraktiewe brein die oer "appetite for poetry", soos Kermode een van sy publikasies betitel (1989), en wat die artistieke teks se visioen of skopus moontlik maak? Die kompetente leser, wat Kermode die "Common Reader" noem, is vir hom diegene, ... "who, as people speak with the past and know something of reading as an art to be mastered" (Kermode 1989:58).

11. Jakobson (1981:99) haal Lowth soos volg aan: "The correspondence of one Verse, or Line, with another, I call Parallelism. When a proposition is delivered, and a second is subjoined to it, or drawn under it, equivalent, or contrasted with it, in Sense; or familiar to it in the form of grammatical construction; these I call Parallel Lines; and the words or phrases answering one to another in the corresponding Lines, Parallel Terms.

Parallel Lines may be reduced to Three sorts; Parallels Synonymous, Parallels Antithetic, and Parallels Synthetic. It is to be observed that the several sorts of Parallels are perpetually mixed with one another; and this mixture gives a variety and beauty to the composition".

12. Turner (1991:91) wys verder daarop: "I find it remarkable that we can grasp symmetric structures in poetry quickly, intuitively, and completely, ...Our ease in recognizing symmetries, of all sorts, may lead us into thinking that we are dealing with something simple, but that would be a mistake... Our understanding of the obvious is complicated". 


\section{Digterlike taal as eksegeet}

Die Afrikaanse digter-literator T.T.Cloete, het teoreties (1970:176-196) sowel as digterlik breedvoerig rekenskap gegee van die eiesoortigheid van die digterlike manier van dink. Hy tipeer dit as 'n dromende denke omdat dit, soos in die geval van die denkstruktuur van die droom, hoofsaaklik deur middel van gesigs- en klankbeelde kommunikeer. Dit is ' $\mathrm{n}$ denkwyse wat tegelyk vry en gebonde is. Enersyds wys Cloete (CSD/SWO Bulletin $5[(6): 7]$ daarop dat gedigteskrywe negentig persent onbewuste werksaamheid is. Hy haal die Nederlandse eksperimentele digters aan wat gesê het: "Jy skryf om te ontdek wat jy weet". Andersyds is dit dié soort "nie weet nie", "goed weet" van die digterlike "kombuisketelstoom"-verbeelding, by implikasie 'n transformasie proses met verskillende vlakke van gelyktydig "weet", soos dit getipeer word in die gedig Paser 2 (Cloete 1998:71). Juis hierdie ineenvloei van bewussynsvlakke tipeer dit as 'n kompetente vorm van "weet", ondanks die feit dat dit nie 'n eksplisiete "weet" is nie. 'n Gedig waarin iets hiervan duidelik word, is die volgende versreëls uit Fragmente (Cloete 1982:24):

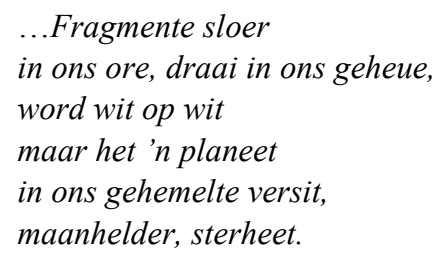

Dit is af te lei uit die gedig dat die digterlike "weet", soos die digterlike manier van dink, eiesoortig is. Dit gaan nie om feitelike kennis nie maar om die digterlike gesigshoek wat ontplof in 'n sterrereën.

Anders as wat waarskynlik van die droom verwag word, is die digterlike droomdenke 'n vormende denke ${ }^{13}$ wat hiper selfbewus skep. Dit is die "vormavontuur" van die digter wat van "die gedig 'n skouspel en geestelike spel maak" (Cloete 1970:193). Die digter is self meegevoer hierdeur. Dit skep egter identifisering én distansiëring. Die digter, beskouer van homself, word toeskouer van homself, en die gedig, middel by die selfbemoeienis, skep tegelyk iets aparts (Cloete 1970:184). Dit relativeer die posisie van die digter as meester van sy eie gedig.

Poësie sou 'n mens kan tipeer as geïntensiveerde taalgebruik. Die digter se begeesterde sien maak van hom 'n taalbesetene, toegespits op sy instrument om dit te laat "uitreik / tot aan die afrandsel van (sy) kyk" (Cloete 1998:70 Paser 1). Hieruit blyk die noue interaksie tussen kyk, literêr gesproke Gesigspunt (point de vue), ${ }^{14}$ en taal. Betekenisvol in dié verband is Mark Turner (1991:187) se opmerking: "Understanding is seeing: To understand the meaning of words is metaphorically to see what they have to present". Die digterlike interstellêre manier van kyk, maak hom andersyds bewus daarvan dat sy taalhantering niks meer as 'n "stamel" is nie (Cloete 1986:130). ${ }^{15}$. Die digter as "die rooimiergeaarde" wat "Driftig dag en nag ... op soek (is) / na 'n pendoring om iets van God / ... vas te pen in 'n kladboek." word gekontrasteer met "die hele kamp (wat) knus snork" in sy Paser 1-gedig. ${ }^{16}$ Vir "Die Vergeetagtige Toeskouer" is die hiperaktiewe kyker "sy goedweteronderhouer" (Cloete 1986:131). Hy beoefen 'n bewaringskuns. Taal én wêreld is geborge in die gedig

13. Vgl Cloete (1970:172): "Op talryke wyses verdig die dromende denke sy gedagtes formeel".

14. Dit dui aan die posisie van die kyker met betrekking tot die tekswêreld (Vgl. Van Gorp 1986).

15. Vgl. stamel (Cloete 1986:130) se 2 slotstrofes: is julle daarvan bewus / julle met woorde toegerus // dat ons vgl. hierbo moet stamel / al is dit ook hoe skamel.

16. Cloete (1970:174) haal byvoorbeeld Marthinus Nijhoff soos volg aan: "Schrijven is merkbaar leven". 
(die paradoksale weerlose "kladboek"). Die begaafde digter is in alle opsigte die taalseismograaf wat gevoelig die soort instrument wat hy/sy hanteer, koester. Hievan is reeds af te lei dat poësie vir enige leser wat onderskeidend moet lees 'n padvinder is.

Naas die onverantwoordbare, is gedigte maak 'n bewustelike proses. God en lewe ${ }^{17}$ word ver-teks via 'n digterlike pen. ${ }^{18}$ Dit impliseer verskillende transponerings - "sien" wat die digter tipeer as 'n versamelsien (1989:181), word ver-taal in digterlike tekens, getipeer as "taaldinkversameling" (1986:131), en ver-teks in 'n netwerk verdigte sisteme wat Cloete tipeer as die amalgaam van die gedig (1986:99). In die gedig Swak ö̈ (1989:174) gee die alte menslike digter voorkeur aan "die saamraapsel" bo "die ewigheid van die rein heelheid...". Die bewussyn van bo-natuurlike handeling word deurgaans in Cloete se oeuvre gejukstaponeer met weerloosheid. In die gedig Rotsode (1982:16), opgedra aan DJ Opperman, lui dit: "hy’t vanaf die inferno tot/in die hemele na die voorbeeld van Dante/afgeluister tot in die buurt van God." ... "maar hy is ook 'n verleë/afhanklike...".

Die dubbelsinnighede en die veelvlakkigheid van taal is die boustene waarmee die digter ' $n$ maaksel tot stand bring wat toegespits is op noukeurigheid. Die digter het nie, soos normale sprekers, meer woorde nodig om te sê wat hy nie kan sê nie. ${ }^{19} \mathrm{Hy} /$ sy is daarop ingestel om minder maar noukeuriger woorde te gebruik om meer te sê. As gevolg van woordkuns se ingesteldheid op die verbindingskuns van woorde, neem woorde vele gedaantes aan. ${ }^{20}$ Hieruit spruit voort dat "digters weet hoe woorde kan lieg". ${ }^{21}$ Wanneer Jakobson rekenskap gee van What is poetry? (1981:742), lewer hy soos volg kommentaar hierop: "The artist is playing no less a game when he announces that this time he is dealing with naked Wahrheit rather than Dichtung as when he assures his audience that a given work is sheer invention, that poetry as a whole is one big lie, and the poet who fails to lie audaciously from the word go is worthless". In dié verband is ook die Franse digter en filmmaker Jean Cocteau se uitspraak betekenisvol: "The poet is a lier who always speaks the truth", terwyl Picasso se weergawe lui: "Art is a lie that makes us realize the truth". In Cloete se gedig Fragment (1985:32) lui dit: Dis die dwaas wat die storie vir 'n leuen / aansien (en dit gaan hier spesifiek oor "die ware verhaal / van die oorbekende varkverlore seun"). Dit is, volgens die digter, "gans anders as vermaaklike huigelary".

In sy soek na antwoorde op die vraag na die onderskeidende eienskappe van poësie, gebruik Jakobson (1981:740) as motto die volgende aanhaling: "Harmony is the result of contrast... The whole world is made up of opposing elements... And ...true poetry - the more original and alive its world, the more contradictory the contrasts in which the secret kinship occurs". Vir die digter is die ontdekking van harmonie in dissonansie 'n vormontwaking soos Cloete in die slotreëls van die gedig Wakker word (1985:12) demonstreer:

...Dit is 'n wonder: uit wat afstoot

en ontroer, wat knel en beroer, walg en bekoor

ontstaan daar tog leefbaar ' $n$ sintoon. ${ }^{22}$

17. Vgl. Paser 1 (1998:70): Ek sien die lewe gelyf.../ Ek kan iets blywends opskryf...

18. Die slot- en beginreëls van voëls met nuwe teks (1986:11) lui: voëls bring met dagbreek / nuwe teks aan... // hulle dra dag en nag teks aan...

19. Cloete (1970:118) haal Van Wyk Louw soos volg aan: "Hierdie geknoopte en gekoekte kosmos durf die Mens met die simpelste, stompste begrippe aan".

20. In Ballade van die digter (1986:66) word van die digter gesê: ...Die digter hou woorde aan die lewe / terwyl soldate in Viëtnam en Thermopylae sterf.

21. Cloete gebruik die titel Die waarheid gelieg (1984) vir sy kortverhaalbundel met die volgende afdelings: 1 . dichters liegen de waarheid; 11....weet ons mos: hoe digters lieg?; 111. lie creatively; $1 \mathrm{~V}$. alles leugens.

22. Let op die harmonieuse sirkelvormige oo's van die eindryme, wat in die hele gedig ook prominent is. 
Teen die besef in dat alle taalpogings "beduimelaars" is (volgens WAT: "deur betasting bevuil") en die oorweldigende besef (1989:145) - ...in die leemtes ontsnap / Iets Groots alle taal en wetenskap..., (hou) "die digter ...aan met dig" (1986:66), "voer hy" "'n roekelose ydel gesprek / met ewighede". Hierdie soort bewussyn kan vergelyk word met wat die filosoof Derrida (2002:30) skryf na anleiding van "religieuse taal". Hy stel die vraag: "Concerning that about which one cannot speak, isn't it best to remain silent?" Dit gaan vir Derrida in die artikel om "exploring and deploying language (at) the resources of negative theology, and with reading its languages". Dit gee aanleiding tot die vraagstelling: "'How not to speak' and 'how to avoid speaking...' 'how not to speak' speaks of something other than avoidance, otherwise than avoidance. If it is the case that there is avoidance in 'how not to speak', there is also, as Derrida explains, a speaking, an affirmation of the impossibility not to speak, indeed, an obligation to speak - which may be impossible to fulfill - but without avoidance, perhaps beyond or otherwise than avoidance". Hierdie "otherwise than avoidance" word deur Derrida getipeer as "the abyss" (Derrida 2002:29). In die poësie kan die wit van die teks net so betekenisgenererend wees soos die tekengebruik. Dit is eweneens 'n vorm van vermyding. TT Cloete verwys veelseggend na sulke openinge in die gedig as "luisterholtes".

\section{Die laserfunksie van taal}

Teen hierdie agtergrond kan Cloete se twee gedigte Paser 1 en Paser 2 (1998:70-72) ondersoek word as laboratorium eksemplaar van die gedrag van die poëtiese funksie van taal. Cloete kan om twee redes betekenisvol wees binne hierdie konteks. Hy gee nie slegs blyke dat hy die Bybelse teksmateriaal as artistieke teks lees wat digterlike reaksie uitlok nie. Hy herken die "waarneembare" of "ondersoekbare" skepping as kunswerk wat stimuleer om "gelees" te word in "Sy deurlopende multimultimeervoud" (1986:133).

Die digterlike instrument is nie tydruimtelik beperk (ingeperk) nie omdat dit in die eerste plek ' $n$ verbindingskuns is wat grense transendeer. Dit is vir Cloete sowel 'n laserkuns (Taallaser 1992:3) as 'n hieroglief-kuns. (1992:4). Die slotreël van laasgenoemde gedig lui:

"In in die taal se meegewende lyf / word deur die digter diep gevoelig ingegryf". ${ }^{23}$

Dit sluit aan by Jakobson se teorie oor die vooropstelling van die "grammatika van poësie" en "die poësie van grammatika" (1981:87-97). Die leser word gelei om eweneens "in in die taal se meegewende lyf' in te lees omdat dit 'n reaksie word op die verligtingstegnieke van die taallaser.

In dieselfde bundel (1998:2) word na die "penkop" (1998:68) se "pendoring" (wat lewe vas-pen) ook verwys as 'n outydse plaasskoolpen ... een met 'n skerp nip / van bruin blik met 'n haaslip, oënskynlik inkompetent naas die laser. Dit funksioneer egter paradoksaal op verbeeldingryke wyse net so effektief om die gevaar op sy hakke (by implikasie die dood/verganklikheid) te "(ver)teken"! Die verwisseling van metafore vir die digterlike skryfinstrument is ' $\mathrm{n}$ aanduiding dat elke metafoor metonimies is - 'n aspek van ' $\mathrm{n}$ onoorsigtelike meervoud. Dit is 'n ongedateerde, multifunksionele medium.

Albei die Paser-gedigte (Paser 1 en Paser 2, 1998: 70, 71), kan gelees word as 'n digterlike dramatisering van die funksionering van die poëtiese funksie van taal. Paser is gevorm na aanleiding van die akroniem laser wat staan vir light amplification by stimulated emmision of radiation. $\mathrm{Na}$ analogie hiervan kan afgelei word dat Paser, poetic amplification by stimulated emmision of radiation is. Hierdie akroniem sluit dus onder

23. Frye 1982:5 wys daarop: "The hieroglyphic phase, for Vico, is a 'poetic use' of language". 
andere aan by die gedig Taallaser (1992:3), in die bundel voorafgaande aan Uit die hoek van my oog, waarin die twee Paser-gedigte voorkom.

Die laser is een van die uitvindings van die eietydse wetenskap wat mikrokosmosse en makrokosmosse verken. Sedert die splitsing van die atoom het nog geen ander ontdekking die wetenskaplikes so opgewonde gehad as die ontdekking van dié unieke ligbron. Laser het ontsaglike moontlikhede. Dit is 'n besonder suiwer, gekonsentreerde straal lig wat deur 'n apparaat, 'n laser, uitgestraal word en bestaan uit lig atome met dieselfde golflengte. Anders as 'n gewone ligstraal wat uit 'n verskeidenheid golflengtes bestaan en in 'n hele klomp rigtings versprei, is die golflengtes van die ligstrale van 'n laserstraal baie eenvormig en parallel, en kan tot op 'n speldpunt gekonsentreer word. Dit is 'n proses waardeur lig versterk word deur lig te gebruik om die uitstraling van meer lig te stimuleer met behulp van opgewekte atome of molekules (WAT). Laserlig help wetenskaplikes nie om "alles" te sien nie. Dit help slegs om te sien dat daar nog meer is om te sien. Die geweldige bandwydte van laserlig en die groot dravermoë daarvan vir inligting is eienskappe wat die gebruik van lasers in kommunikasiestelsels buitengewoon funksioneel maak. 'n Laserstraal word, belangrik veral vir teksstudies, gebruik om 'n hologram te skep (Griffiths 1989:22 e.v.). Dit is 'n driedimensionele beeld wat deur laserlig ontstaan sonder die gebruik van 'n lens. Die toepaslikheid van hierdie omvattende metafoor as verwysing na die kreatiewe poëtiese funksie van taal is voor die hand liggend.

Die oog is 'n ligdekodeerder en in dié opsig verwant aan die laser. Dit is betekenisvol dat die Paser-gedigte voorkom in die bundel Uit die hoek van my oog. Die oog (soos veelseggend die son) is ' $\mathrm{n}$ deurlopende motief in Cloete se oeuvre. ${ }^{24}$ Die digterlike oog word gestimuleer deur geïntensiveerde lig ("amplification ... by radiation"), 'n vorm van heldersiendheid. Dit is 'n refleksiewe funksie. Daarom is daar sprake van Die Eerste Oog, die Laseroog. Die son is, simbolies gesien, 'n ligoorsprong en lig is simbolies van die intellek en die spirituele. Sien as 'n verstaansproses (Cirlot 1982:99) word dus sowel intellektueel as spiritueel geaktiveer. ${ }^{25}$

Die eerste Paser-gedig begin met 'n oënskynlik onbenullige waarneming - "Die klein swart voëltjie eet / by Satara met sy rooi snawel / goggatjies voor my rondawel." Hier word oënskynlik in besonderhede waargeneem. Die digterlike sien gaan analogies "in vlug" wanneer die "voëltjie wegvlieg" en die vergelyking: "soos 'n komeet / - lang dun stert...", in die gedig gemanifesteer word. 'n Metaforiese proses word geaktiveer wat sowel semanties as klankmatig evolueer. "Amplification" verwys dus nie slegs na digterlike hipertensie (volgens Paser 1, by implikasie slaaploosheid) nie maar na taalkundige versterking, vergroting, aanvulling van die aanvanklike waarneming.

Die eerste wat opval, is dat die anvanklike konteks van die Paser 1 -gedig in die tweede Paser-gedig verplaas word. Oënskynlik hou die ver-beeldingsproses hier geen verband met dié van die eerste gedig nie. Noukeuriger aandag ontdek egter spoedig raakpunte tussen die twee gedig-kontekste. In die eerste strofe van Paser 2 word gekontrasteer tussen "veraf ... en hoog", "verblindende ver", "agter die verste wordende ster" en "om die kosbare nietighede te aanskou" en "in die oog te hou", wat Paser 1 betrek. Dit blyk deur middel van die beeldontwikkeling in Paser 2 dat hier sprake is van wêrelde in wording wat ruimtes (kontekste) relativeer. Analogies ervaar die waarnemer 'n geboorteproses ("ek voel en groei

24. Vgl. Plotinus wat gesê het die oog sou nie in staat gewees het om die son te sien as dit nie self 'n son was nie (Cirlot 1982:99).

25. Vgl. die Nederlandse digter-skrywer Harry Mulisch (1961:39) se soortgelyke ervaring: "Ik ontwikkel iets anders, dat onschatbaarder is dan meningen, een orgaan, dat mijn hele lichaam gebruikt om zich te vormen: HET OOG. Langzaam verander ik in een groot oog, dat kijkt. Dat schrijft”. 
in die wordende wording saam soos 'n / fetus."). Daar word ook uitdruklike kontraste geskep tussen "geheueloos / lank gelede", "ver terug tevore" en "moet verbygaan", teenoor "vandág dié dag".

In ooreenstemming met Einstein se insigte (vgl. Boorstin 1999:301) blyk dit uit die twee gedigte hoe tydruimte relatief verskillend funksioneer in statiese en bewegende sisteme. “...Deurkyk is ryker as vasstaar”, lui dit in nog 'n oog-gedig (1992:87). In Paser 2 word verwys na "boustukke van 'n legkaart" wat deur die digterlike bewegende sien sigbaar word, ondanks die oënskynlike verbandloosheid van die beeldspraak (vgl. in strofe 2 van Paser 2: 'n boom, man met 'n baard, vet merinoskape ... in 'n trop/wol, blomkoolkoppe). Ook wanneer die leser "in beweging" sien, begin al meer legkaartstukke nader na mekaar beweeg. Die "klein swart voëltjie" van Paser 1 se "lang dun stert" skep die analoog met 'n hemelliggaam, 'n komeet. In Paser 2 beweeg die "paser" soos 'n ruimtetuig (Hubble). "Hy" (die digterlike laseroog) ry egter ook op Pegasus, die gevleuelde perd uit die Griekse mitologie wat met die kap van sy hoef die fontein van die Muse op Helikon kon laat opborrel. Pegasus is egter ook, soos Hubble, 'n byderwetse ruimtetuig wat buite-ruimtelike inligting versamel. Onafwendbaar skep dit 'n verdere verband met die sterrestelsel Pegasus wat deel vorm van 'n kosmologie, soos elke bewegende partikel van die twee gedigte uiteindelik deel vorm van 'n metaforiese sterrestelsel.

Isotopieë word dus geaktiveer in albei gedigte onderskeidelik deur die eerste paar versreëls van Paser 1. Dit skep eenheid tussen die twee gedigte wat met 'n eerste oogopslag nie opsigtelik bymekaar aansluit nie. Binne die gedigverband roep die voëltjie ook die voëlveer as simbool van die skryfkuns op, wat aansluit by die isotopie "pendoring" (skerppuntige doring gebruik as skryfapparaat) en die ontwikkeling tot die gesofistikeerde byderwetse Paser motiveer. Die "pendoring" tipeer etimologies 'n kultureel eiesoortige skryfapparaat waarvan die gebruik die eerste keer opgeteken is in 1880 by Pannevis (Van Wyk red. 2003:343). Met inagneming van die verwysing na "die berge en rante" wat "geheueloos / lank gelede gemaak is... // ...toe was my taal nog nie eens gebore" nie, kan ook afgelei word dat die skepping (as teks) nie saamval met taal (as ver-tolking) nie (vgl. die versreël: "ek [sal] vir die regie sorg"). Dit relativeer 'n referensiële funksie in 'n benadering van die teksmateriaal. Daar is eiesinnige faktore in die skepping wat die sig stuit ("Hier en daar rondom is 'n muur...") of versluier ("ongedurig word die donker aangedik").

Die mitologiese Pegasus word in die laaste strofe van Paser 2 "my blikperd". Laasgenoemde "blikperd" kan egter ook verwys na Hubble in die voorafgaande strofe. Met inagneming van die vroeër verwysing na die "outydse plaasskoolpen... / ...met 'n skerp nip / van bruin blik" (1998:2) wat die dood kon ver-teken, is hierdie verbandlegging betekenisvol. Dieselfde "blikperd" samel in die Paser 2-gedig ruimte-inligting in, by implikasie ook as weerstand teen tydruimtelike wisselvalligheid. Dié isotopie suggereer 'n voëlvlug ontwikkelingsgeskiedenis van die digterlike skryfapparaat in pas met eietydse wetenskaplike kennis.

Die gesigshoek van die digter, sy "ver skelm reisende oë" (1986:107) wat buitenstyds en buiteruimtelik waarneem (vgl. Pegasus, mitologies en Hubble, wetenskaplik) sowel as "digby intiem rondsien" (Paser 2), noodsaak dié soort taalgebruik wat met die funksionering van die gesofistikeerde laser vergelyk kan word - dit is die Paser of die poëtiese funksie. Synde oog-afhanklik, word dit gestimuleer deur lig van elders - 'n "Eerste Oog", vanselfsprekend 'n Laseroog as die funksionering van laserlig in aanmerking geneem word. Die in werkingstelling van die poëtiese funksie, impliseer na aanleiding van Cloete se metafoorgebruik van die taallaser, 'n vorm van suiwer en gekonsentreerde verligting van 'n talige teks wat dit tydruimtelik relativeer ten einde nuwe verbande sigbaar te maak. In 
die lig van die wetenskaplike gesofistikeerdheid van dié metafoor, beteken dit dat ook die fotons (WAT: ligkwantums, eenheid van visuele prikkeling, wat die helderheidsindruk wat verkry word, bepaal) 'n rol speel. Dit vra van die leser om so van gesigshoek te kan verander dat eweneens sowel die omvattende (subteks en interteks) as die partikuliere (taalkwantums) in die oog gehou kan word. Daar moet met ander woorde meerdimensioneel waargeneem word. Dit impliseer bewegende lees - die onderneem van 'n ruimtereis wat 'n "ont-aarding" beklemtoon. (volgens die gedig word die waarnemer "'n bewegende rondawel"), met 'n gefokusde moment as uitgangspunt ("vandag is die dag"). Dit lei tot die ontstaan van 'n nuwe skeppingswonder - 'n figuurlike "nuwe aarde" ("ek voel en groei in die wordende wording saam soos 'n / fetus").

David Tracy onderskei insiggewend in The analogical Imagination (1991:125) die kunstenaar (en geesgenote) se manier van dink soos volg:

"The artist, the thinker, the hero, the saint - who are they, finally, but the finite self radicalized and intensified. The difference between the artist and the rest of us is one of intense degree, not of kind ... The surest sign of the artist is not a striking originality in the sense of novelty and is never a self embodied in a finite tradition - even if a despised tradition... The sign of the artist may well be a willingness to undergo the journey of intensification into particularity to the point where an originating sense for the fundamental questions and feelings that impell us all, and a rare response in thought and feeling to those questions, is experienced - and often experienced as some kind of gift, come 'unawares'. Then the experience ... is rendered through all the strategies of semblance of the productive, creative imagination into the actuality of the work of art".

Die uitdaging vir die kreatiewe leser is om die visioenêre oop teks "af te rond" maar oop te laat bly - om ontvanklik te wees vir die geheel te midde van eindelose ander "gehele" (holons volgens die filosoof, Ken Wilber 2001:121)

\section{Mitologie}

By die lees van artistieke tekste is dit betekenisvol om die begrip mythos, (gesproke woord), soos dit oorspronklik in Grieks gebruik is in teenstelling tot logos, in berekening te bring. Mythos was, let wel, die verhaal van 'n digter, terwyl logos 'n betroubare verslag of waarheidsgetroue uiteensetting was (Van Gorp 1986). Vandaar het mite 'n negatiewe waarde verwerf en is dit gebruik vir alles wat met die werklikheid in stryd is. Oorspronklik is 'n dubbele niveau onderskei in die mite - enersyds die idee agter 'n verhaal en andersyds die narratiewe inkleding wat slegs die metafoor was daarvoor. Dit roep weer Cloete se "creative lying" op.

Verskillende digters en filosowe argumenteer dat 'n metaforiese reaksie op die "wêreld" 'n baie primitiewe een, in die sin van oerbekend, is; dit funsksioneer op grond van die behoefte om die onbekende te verstaan d.m.v. dit wat reeds verstaan is of om op 'n nuwe wyse na ou dinge te kyk. Dit is waarom kindertaal so verrassend nuut kan wees in 'n proses van taalverwerwing. Volgens Ricoeur (1995:160) is dit die metaforiseringsproses, meer as enigiets anders, wat die leser se produktiewe verbeelding stimuleer. Mythos, dié wat te maak het met die verhaal van die digter, kan deur eenvoudiges verstaan word maar is te diep vir teoretici om te deurgrond.

Sê dit iets vir die Bybelse kanon as dokument van die verbeelding (vgl. Ricoeur in Betz 1981)? Is die digterlike ervaring outentiek? Is digterlike "openbaring" kontekstueel? Is dit verifieerbaar?, Volgens Cloete (1998:68) se gedig, penkop hoor meer as een stem word geen ander teken/bewys/verifiëring aan die geïnspireerde gegee nie as die teks. Veelseggend is dan die gevolgtrekking van Karl Barth (1981:79), wanneer hy kommentaar 
lewer op die Onse Vader: "All human errors and aberrations can be compensated for and made good, but not the inordinate desire of one who in calling upon God wants to meet him, and thinks he can meet Him, in more imposing fashion than as a newly registered pupil”.

\section{Slotsom}

Die digter is, volgens Cloete (1982:16), 'n skisognatis, ${ }^{26}$ die Paser, in alle opsigte ambivalent. Laasgenoemde is meerduidig en spesifiek. Dit is tydsgebonde en tydloos, gedekontekstualiseer maar gerekontekstualiseer. Ten spyte van die spel wat dit toelaat t.o.v. betekenistoekenning, konstrueer dit betekenisryke netwerke in die plek van leegte. Dit is tegelyk openbaring van die niks en verhulling van die niks omdat dit deur en verby die verhulling verken. Dit is selfs verkulling, afhangende van "die hoek van die oog". Dit is om tydruimtelikheid in die vorm van 'n gedig te rekonstrueer te midde van oënskynlike leegte. Dit is en dit is nie. Dit is poetic amplification by stimulated emmision of radiation. Die digterlike laser maak "oë ... wat glasblind staar bysiende maar gester / helder gerig op die verste ster" (Cloete 1985:113). Dit sien hologramme i.p.v. plat vlakke op papier met 'n voor en agter en binne die teks. Dit transformeer die begrensde teks tot venster. Dit is daarop gerig om misteries misteries te laat bly. Dalk is dít openbaring én verhulling.

26. Iemand met ' $n$ gesplete verhemelte. 


\section{LITERATUURLYS}

Alter, Robert \& Kermode, Frank (eds.) 1987. The Literary Guide to the Bible. London: Collins.

Armstrong, Daniel \& Van Schooneveld, CH 1977. Roman Jakobson. Echoes of his Scholarship. Lisse: The Peter De Ridder Press.

Barth, Karl, Bromiley, Geoffrey W 1981. The Christian Life. Church Dogmatics 1V, 4 Lecture Fragments. Grand Rapids: William B Eerdmans.

Betz, Hans Dieter (ed.) 1981. The Bible as a Document of the University. Chicago: Scolars Press.

Birch, David 1989. Language,Lliterature and Critical Practice: Ways of Analysing Text. London: Routledge.

Boorstin, Daniel J 1999. The Seekers. New York: Vintage Books.

Bradford, Richard 1994. Roman Jakobson. Life, Language, Art. London: Routledge.

Chomsky, Noam 2000. New Horizons in the Study of Language and Mind. Cambridge: UniversityPress.

Cirlot, JE (1962) 1982. A Dictionary of Symbols. London: Routledge and Kegan Paul.

Cloete, TT xxxx (jaartal?) Profiel in CSO/SWB 5(6):7. 1970. Kaneel. Studies oor die poësie, prosa en die kunsteorie. Kaapstad: Nasionale Boekhandel.

1982. Jukstaposisie. Kaapstad: Tafelberg.

1984. Die waarheid gelieg. Kaapstad: Tafelberg.

1985. Allotroop. Kaapstad: Tafelberg.

1986. Idiolek. Kaapstad: Tafelberg.

1989. Driepas. Kaapstad: Tafelberg.

1992. Met die aarde praat. Kaapstad: Tafelberg.

(red.). 1992/11. Literêre Terme \& Teorieë. Pretoria: HAUM-Literêr.

1998. Uit die hoek van my oog. Kaapstad:Tafelberg.

Denby, David. (1996) 1997. Great Books. New York: Touchstone.

Derrida, Jacques. Anidjar, Gil. (ed.) 2002. Acts of Religion. New York: Routledge.

Eco, Umberto. (1979) 1983. The Role of the Reader. Explorations in the Semiotics of Texts. London: Hutchinson.

Fokkema, DW and Kunne-Ibsch, Elrud (1977) 1079. Theories of Literature in the Twentieth Century. London: C Hurst.

Fokkema, Douwe, W 1985. The Concept of Code in the Study of Literature. Poetics Today, Vol.6:4, 643-656.

Frye, Northrop 1982. The Great Code. The Bible and Literature. London: Routledge.

Griffiths, John, Koen, JW (vert.)1989. Lasers en hologramme. Kaapstad: Tafelberg.

Halle, Morris (compl.) 1956. For Roman Jakobson. Essays on the Occasion of his $60^{\text {th }}$ Birthday. The Hague: Mouton.

Halliday, MAK 1985. An Introduction to Functional Grammar. London: Edward Arnold.

Halliday, MAK \& Matthiessen, Christian MIM 1999. Construing Experience through Meaning. A Language-based Approach to Cognition. London: Cassell.

Jakobson, Roman 1981. Selected Writings 111. Poetry of Grammar and Grammar of Poetry. New York: Mouton. 
Jefferson, Ann \& Robey, David (1982) 1991. Modern Literary Theory. A Comparative Introduction. London: BT Batsford.

Kermode, Frank (1989) 1990. An Appetite for Poetry. Essays in Literary Interpretation 1990. Poetry, Narrative, History. Oxford: Basil Blackwill.

Mudge, Lewis S (ed.) 1980. Essays on Biblical Interpretation. Fortress Press.

Mulisch, Harry 1961. Voer voor psychologen. Amsterdam: De Bezige Bij.

Preminger, Alex \& Brogan, TVF (eds.) 1993. The new Princeton Encyclopedia of Poetry and Poetics. Princeton: Princeton University Press.

Ricoeur, Paul 1974. The Conflict of Interpretations. Evanston: Northwestern University Press.

1995. Figuring the Sacred. Religion, Narrative, and Imagination. Minneapolis: Fortress press.

Roberts, Phil (1986) 2000. How Poetry Works. London: Penguin Books.

Schleifer, Ronald. 1987. AJ Greimas and the Nature of Meaning: Linguistics, Semiotics and Discourde Theory. Kent: Croom Helm.

Scholes, Robert (1974) 1979. Structuralism in Literature. An Introduction. New Haven: Yale University Press.

Scholes, R 1982. Semiotics and Interpretation. New Haven: Yale University Press.

Sebeok, Thomas A 1960. Style in Language. New York: John Wiley and Sons.

Senekal, J (red.) 1986. Teks-leser-konteks. Johannesburg: Perskor.

Shipley, Joseph T (1953) 1968. Dictionary of World Literature. Totowa: Littlefield.

Sternberg, Meir (1985) 1987. The Poetics of Biblical Narrative. Ideological Literature and the Drama of Reading. Bloomington: Indiana University Press.

Thiselton, Anthony C 1992. New Horizons in Hermeneutics. The Theory and Practice of Transforming Bible Reading. Grand Rapids: Zondervan.

Tracy, David (1981) 1991. The Analogical Imagination. Christian Theology and the Culture of Pluralism. New York: Crossroad.

Turner, Mark 1991. Reading Minds. Princeton: Princeton University Press.

Van Dijk, TA 1971. Moderne literatuurteorie. Een eksperimentele inleiding. Amsterdam: Van Gennep.

Van Gorp, H e.a. 1986. Lexicon van Literaire Termen. Groningen: Wokters-Noordhoff.

Van Wyk, GJ (red.) 2003. Etimologiese Woordeboek van Afrikaans. Stellenbosch: WAT.

Ward, Graham (1995) 1998. Barth, Derrida and the Language of Theology. Cambridge: Cambridge University Press.

WAT. Woordeboek van die Afrikaanse taal. Eerste deel A-C 1970. Pretoria: Staatsdrukker.

Wilber, Ken 2001. The Eye of the Spirit. An integral vision for a world gone slightly mad. London: Shambhala. 